\title{
CODING GRAMMATICAL SIGNALS IN WESTERN TAMANG: A TYPOLOGICAL PERSPECTIVE
}

Dan Raj Regmi

Western Tamang differs from Eastern Tamang while coding grammatical signals by different morphosyntactic devices especially at propositional information level. Both dialects almost equally share most of the common structural features of Bodish group. However, dialect specific differences have to be compared from a typological perspective for practical implications in Tamang.

Keywords: coding devices, grammatical signals, ergative case marking, reflexive marking, language development

\section{Background}

This paper briefly looks at some major coding devices of grammatical signals in Western Tamang [WT, ISO code tdg] and compares them with those employed in Eastern Tamang (ET) from a typological perspective for practical implications such as status and corpus planning in the Tamang language. ${ }^{1}$ Western Tamang is a dialect of Tamang, others being Eastern Tamang [taj], Eastern Gorkha Tamang [tge], Northwestern Tamang [tmk], Southwestern Tamang [tsf] (Eppele et al., 2012). The $\mathrm{CBS} / \mathrm{N}$ report (2012) has not counted the number of speakers of WT separately. WT is a complex tonal, consistently ergative, aspect prominent, highly embedding and extremely nominalizing dialect of Tamang (Regmi and Regmi, 2018). Tamang, in general, is a safe/vigorous Tibeto-Burman languages spoken by about $1,353,311(87.9 \%)$ of a total of $1,539,830$ ethnic Tamang, most of them living in central Nepal particularly the hilly areas around the Kathmandu valley (CBS, 2012). Map 1.1 presents the geo-linguistic situation of the dialects of Tamang including Western Tamang.

\footnotetext{
${ }^{1}$ This is a revised version of the paper presented at the $39^{\text {th }}$ Annual Conference of Linguistic Society of Nepal held in CEDA Hall,Tribhuvan University, Kirtipur, Nepal [November 26-27, 2018]
}

Nepalese Linguistics, vol. 34, 2019, pp. 43-51.

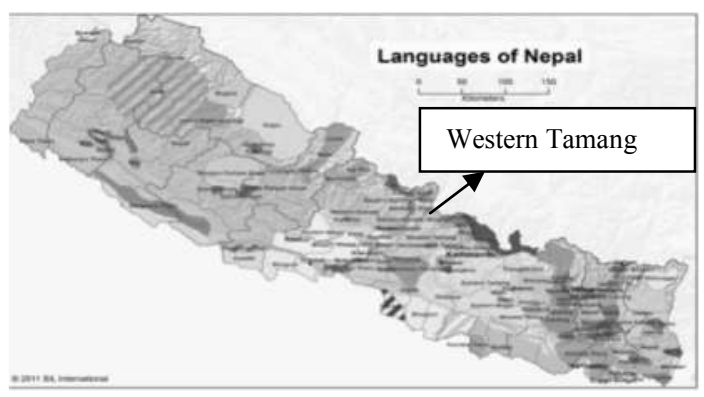

Map 1.1 shows that WT is exclusively spoken in Bagmati and Narayani Zones. In Bagmati Zone, it is spoken in west Nuwakot, Rasuwa, Dhading districts, northeastern Sindhupalchok District, Bhote Namlan, Bhote Chaur, west bank of Trishuli River towards Budhi Gandaki River. In Narayani Zone, it is mainly spoken in northwestern Makwanpur District, Phakel, Chakhel, Kulekhani, Markhu, Tistung, Palung; northern Kathmandu, Jhor, Thoka, Gagal Phedi (Eppele et al., 2012). Tamang is classified as one of the members of the Gurung-Tamang cluster of West Bodish sub-section of the Bodish section of Bodic branch of TB (Eppele et al., 2012). Figure 1.1 presents the position of Tamang and their major dialects including Western Tamang among the TB languages of Nepal (based on Bradley 1997/2002).

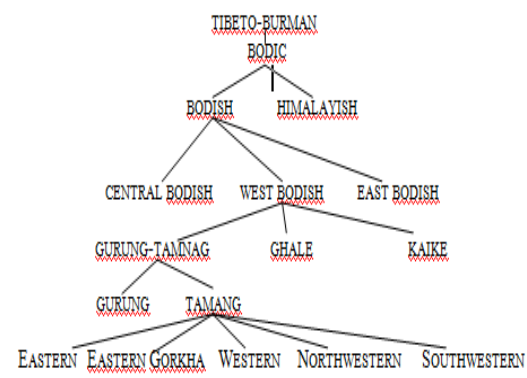

Figure 1.1: Position of Western Tamang with other major dialects among the TibetoBurman languages 
44 / Coding grammatical signals...

Tamang spoken to the east of the Trishuli River, in general, has been referred to as Eastern Tamang (Yonjan-Tamang (2016:2). There are a few previous studies in Western Tamang. They include Hari et al. (1970), Taylor (1973), Tamang (1994), Chalise (2003), Lipp (2014), Adhikari (2015), Thokar (2015), SIL (2017), Regmi (2017), Regmi and Regmi (2018) and Regmi and Regmi (2019). There are a few previous studies in Eastern Tamang. They include Varenkamp (1996), Lee (2011), Mazaudon (2003), Poudel (2006), Owen-Smith, (2015),Yonjan-Tamang (2016) and Yadav (2018). These dialects almost equally share most of the common structural features of Bodish group. However, they exhibit dialect specific differences. Such differences are manifested primarily at the propositional information level. This level is coded by different morphosyntactic devices. More specifically, dialectal differences are apparent in the domain of verb morphology. Such differences require being compared from a typological perspective for practical implications in Tamang.

In this paper, both primary and secondary data have been employed. Data for Eastern Tamang has been gleaned primarily from Lee (2011), Mazaudon (2003), Poudel (2006), Owen-Smith, (2015) and Yonjan-Tamang (2016) whereas data for Western Tamang are based on the field study and partially used in Regmi and Regmi (2018).

This paper is organized into seven sections. In Section 2, we briefly discuss the theoretical underpinning of the paper. Section 3 deals with the coding primary grammatical signals in Western Tamang. In Section 4, we look at the coding secondary grammatical signals in the language. Section 5 compares the coding features of WT, ET and DT (Dhunkute Tamang) with the common features of Bodish group of language. In section 6, we look at the implications of typological perspective in Western Tamang. Section 7 summarizes the findings of the paper with a conclusion.

\section{Theoretical underpinning}

This paper has employed adaptive approach proposed in Givón (2001a, 2001b). The main argument of this approach is that language is a tool for communication composing of forms and functions. More specifically, this approach adheres that forms are adapted for different communicative functions. According to this approach, there are two types of communicative codes: Sensory motor codes and the grammatical codes. Grammar is much more abstract and complex code. There are two types of grammatical signals: Primary and secondary. Primary signals are coded by four major devices: morphology, intonation, rhythmics and sequential order of words or morphemes. Such devices are used to code hierarchy constituency, grammatical relations, syntactic categories, scope and relevance relations and government and control relations (Givón, 2001a \& b). Grammar is a symbolic code and adaptive function (Givón, 2010:34-35) codes propositional semantics and discourse coherence concurrently.

Secondary signals are coded by discourse oriented grammatical sub-systems: grammatical role, definiteness and reference, anaphora, pronouns and agreement, tense, aspect, modality and negation, de-transitive voice, relativization, topicalization, speech acts, focus and contrast, clause conjunction and contrast.

\section{Coding primary grammatical signals}

Western Tamang employs primary grammarcoding devices, viz., morphology, intonation, rhythmic and sequential order of words and morphemes at the propositional information levels in order to code different grammatical signals. Some of the major features of the grammatical code in Western Tamang are briefly presented from a typological perspective as follows:

\subsection{Ergative case-marking}

Like Eastern Tamang (Lee, 2011:87), Western Tamang displays the systemic ergative basically controlled by transitivity. In both dialects, irrespective of tense-aspect, a transitive subject is marked with the ergative suffix consistently as in (1).
(1)

$\begin{array}{lcc}\text { ya-dze } \quad \text { puk }^{\mathrm{h}} \text { ri } & \text { sets-dzi } \\ \text { 1SG-ERG } & \text { snake-ABS } & \text { kill-PFV } \\ \text { 'I killed a snake.' } & \end{array}$


However, Dhankute Tamang exhibits a splitergative with respect to tense-aspect (Poudel, 2006) as in (2a-b). ${ }^{2}$
a. anrita
kan tsa-la
Ang Rita rice eat-IMPFV
'Ang Rita will eat/eats rice.'
b. an rita-se kan tsa-dzi
Ang Rita-ERG rice eat-PFV
'Ang Rita ate rice.'

In example (2a), the nominal subject ay rita is not marked with ergative marker $-s e$ unlike in example (2b) since in example (2a) the verb $t s a$ 'eat' is marked by -la, an imperfective aspect marker in Dhankute Tamang. In example (2b), the verb $t s a$ 'eat' is marked by $-d z i$, a perfective marker. Thus, the nominal subject ay rita has been coded with ergative marker -se.

\subsection{Differential object marking}

Like in Eastern Tamang (Lee, 2011:95-96), human nominal arguments in the role of indirect objects are marked with the dative suffix in Western Tamang.

\section{(3) ram-dze sita-da kələm pin-dzi Ram-ERG Sita-DAT pen give-PFV 'Ram gave Sita a pen.'}

In example (3) the nominal argument sita assumes the role of indirect object. Theoretically, in an ergative-absolutive language like Tamang, the indirect objects are not expected to be overtly marked. However, in Western Tamang, the human indirect objects in a transitive clause are marked by the case inflection $-d a$. It is not an accusative marking as in nominative-accusative languages like Japanese and English. This inflection, viz., $d a$ is basically used for marking a dative case in Western Tamang. Thus, for convenience, it is, however, glossed as the dative case. Such marking is referred to as anti-dative marking (Dryer,1986). In example (3) the nominal argument kələm 'pen' is in the role of direct object. It is coded in the absolutive case, i.e., zero-marked. Such cases are reported in Bhujel (Regmi, 2012) and Magar Kaike (Regmi, 2013).

\footnotetext{
${ }^{2}$ Data 2(a) and 2(b) are from Paudel (2006).
}

\subsection{Numeral classifiers}

Eastern Tamang (Lee, 2011:33) employs numeral classifier suffix -gor for counting any countable objects. Yonjan-Tamang (2016:78) reports that Eastern Tamang employs classifier $-m^{h}$ endo for human nouns and -gor for non-human nouns. Unlike ET, Western Tamang marks numeral classifiers exclusively for human nouns or pronouns by the suffix $-m a$ as in (4).
(4) ro
som-ma $\quad \mathrm{k}^{\mathrm{h}} \mathrm{a}-\mathrm{dzi}$
friend three-CLF come-PFV
'Three friends arrived.'

In Dhankute Tamang (Poudel, 2006), there are two types of classifiers: human (marked by$m^{h}$ endo) and non-human (marked by $-t^{h} i k a$ ).

\subsection{Immediacy marking (remote vs. vivid)}

Eastern Tamang (Yonjan-Tamang, 2016:85) makes a distinction between a remote vs. vivid perspective on the events or sequence of events. In Eastern Tamang, the remote past is marked by suffix: $-t s i /-d z i$. However, vivid events are marked by $-m u$ on the root of the verbs. Such distinction is based on indirect vs. direct evidentiality as in (5).
(5) pasay
dim-ri
kha-mu
Pasang house-LOC
come-PFV
'Pasang came home.'

However, WT does not exhibit such distinction. Neither such distinction is made in Eastern Tamang (Mazaudon, 2003:302). However, in Dhankute Tamang (Poudel, 2006), a distinction is made between simple past (marked by $-t s i /-d z i$ ) and unknown past (marked by -tsim/-dzim) as in (6a-b).
a. Simple past ya-i kan tsa-dzi 1SG-ERG rice eat-PFV 'I ate rice.'

b. Unknown past mui-se sun tsa-dzim buffalo-ERG paddy eat-PFV '(I had not known) buffalo ate paddy.'

\subsection{Causative marking}

The suffix $-n a$ is attached to the root of verb to derive morphological causative verb in Eastern 
46 / Coding grammatical signals...

Tamang (Lee, 2011:105; Yonjan-Tamang, 2016:66) as in (7).

(7) pasay-se palmo-da yet-na
Pasang-ERG Palmo-DAT laugh-CAUS
la-dzi
do-PFV
'Pasang made Palmo laugh.'

However, Owen-Smith (2015:225) argues that Tamang lacks morphological causative. Thus, the suffix- $n a$, which has been analyzed as causative suffix in Eastern Tamang (Lee, 2011:105; Yonjan-Tamang, 2016:66), should be insightfully analyzed as resultative converbial suffix (OwenSmith, 2015:225). A periphrastic causative construction in Tamang is formed by attaching the resultative converbial suffix to the root of the verb. Such verb, which is non-finite, is followed by the verb -la 'do'. This verb is inflected as the finite verb as in (8).

(8) ut-se ya-ta airak thuy-na
that-ERG 1SG-DAT liquor drink-RES
la-tsi
do-PFV
"He forced me to drink liquor."

Unlike Eastern Tamang, the causative is marked by the suffix -myay on the root of verb in Western Tamang as in (9).

$\begin{array}{lll}\text { (9) pasay-se } & \text { palmo-da } & \text { yet-myan } \\ \text { Pasang-ERG } & \text { Palmo-DAT } & \text { laugh-CAUS } \\ \text { la-dzi } & \\ \text { do-PFV } & \\ \text { 'Pasang made Palmo laugh.' }\end{array}$

\subsection{Word order}

The basic constituent order in Tamang transitive clauses is SOV (Lee, 2011:134; Mazaudon, 2003: 293). It is a neutral word-order in Tibeto-Burman languages. Unlike English, the grammatical roles of clause constituents are basically coded by the nominal morphology in Tamang (ET \& WT). WT exhibits marked word-order variants of rigid order of clausal constituents for contrastive topicalization, contrastive focusing, wh-questions and passive construction. ${ }^{3}$ In Western Tamang,

\footnotetext{
${ }^{3}$ See 4.2 for detail about passive construction.
}

possessor is followed by noun whereas demonstratives are preceded by nouns. WT displays a rigid word-order of the peripheral constituents, i.e., modifiers in the noun phrases. It has noun-numeral, noun-adjective, genitive-head and relative clause-head order. In WT, except negation morpheme, all the case-role markers on the nouns and tense-aspect and modality markers on the verbs are cliticized as suffixes.

\subsection{Intonation and stress}

Eastern Tamang employs rising intonation for yes-no as well as content questions (Lee, 2011:147). The falling intonation is used for declarative sentence, content questions and request in Tamang (Yonjan-Tamang, 2016:32). As in Eastern Tamang, the falling intonation is used for declarative and rising intonation is used for yes-no question in WT as in (10).
(10) a
dza-dze ken tsa-ba $\downarrow$
son-ERG rice eat-NMLZ
'The son eats rice.'
b. dza-dze ken tsa-ba $\uparrow$
son-ERG rice eat-NMLZ
'Does the son eat rice?'

The stress is not distinctive in Tamang.

\section{Coding secondary grammatical signals}

Apart from primary grammar-coding devices, Western Tamang, employs some grammatical sub-systems to code primarily discourse pragmatics. Such sub-system may include grammatical relations, tense-aspect, modality and negation, de-transitive voices, relative clauses, contrastive focus and marked topic, coordination and subordination. Western Tamang does not differ from Eastern Tamang in coding grammatical relations, tense-aspect, modality, negation, contrastive focus and marked topic and coordination. Some differences lie in coding detransitive voices, relative clauses, subordination and honorificity. They are briefly discussed as follows:

\subsection{Reflexive marking}

Mazaudon (2003: 298) notes that ET does not have any special reflexive pronouns. The pronoun ray 'self' is suffixed by the dative maker $-t a$ followed by the intensifier $-n$. Lee (2011:37) 
observes that the personal pronoun $r^{h} a \eta$ is also used for the reflexive pronoun in ET. YonjanTamang (2016:55) notes that ray is the reflexive pronoun in Tamang. Unlike Eastern Tamang, the personal pronouns are suffixed by the reflexive marker -tano in Western Tamang as in (11).
(11) ya-tse
ya-tano ts ${ }^{\mathrm{h}}$ ek-tsi
1SG-ERG 1SG-REFLbeat-PFV
'I beat myself.'

\subsection{Passive construction}

Like Sherpa (Givón, 2001 Vol.II:134) Western Tamang exhibits a subtype of non-promotional passive. In such passive construction, the nonagent topic of the passive is not fully promoted to the subject as in promotional passive (Regmi and Regmi, 2018). In such type of passive, the agent/subject of the active is typically missing as in (12).

\section{(12) kola-da məhr wa-dzi child-DAT ghee feed-PFV 'Ghee is fed to the child.'}

The agent/subject of the passive construction in example (12) is missing. In example (12), kola 'child' suffixed by -dais the topic of the passive. It is not fully promoted to the subjecthood as in promotional passive. It is to be noted that the syntax of passive constructions is similar to the direct-active in Western Tamang. Moreover, the order of clausal constituents in example (12) is IODO-V. The agent/subject which is expected to appear before the verb is omitted. Following Givón (2001 Vol. I: 237), we may argue that Western Tamang employs variant word order in passive constructions. The omission of Aargument is discussed in Eastern Tamang (OwenSmith,2015:277) in such constructions.

\subsection{Nominalized relative clauses}

The verb of the relative clause is nominalized by $p a$ in ET (Mazaudon, 2003: 299). Such verb is suffixed by the nominalizer $-b a$ in ET (Lee, 2011:117) as in (13).

\section{(13) bidyarthi-da to-ba sitshək student-DAT beat-NMLZ teacher 'The teacher who beat students'}

Like in ET, the verb of the relative clause is nominalized in Western Tamang. However, unlike in Eastern Tamang, the nominalizer $-b a$ is obligatorily followed by the genitive marker to code perfective aspect in Western Tamang as in (14).

(14) a. Nominalizer being followed by genitive $<$-ba-la $>$

$\operatorname{dim}$ so-ba-la $\quad \mathrm{m}^{\mathrm{h}} \mathrm{i} \mathrm{k}^{\mathrm{h}} \mathrm{a}-\mathrm{dzi}$

house make-NMLZ-GEN man come-PFV

The man who made house has arrived.'

b. Nominalizer only <-ba $>$

$\begin{array}{lll}\text { ya-dze } & \text { dzi } & \text { th }^{\mathrm{h}} \text {-ba } \\ \text { 1SG-ERG } & \text { alcohol drink-NMLZ } \\ \text { mi-ta } & \text { ts }{ }^{\mathrm{h}} \text { ek-tsi } \\ \text { man-DAT beat-PFV } \\ \text { 'I beat the man who drinks alcohol.' }\end{array}$

The former (14a) codes perfective aspect whereas the latter (14b) codes imperfective aspect in Western Tamang.Moreover, due to the prolonged contact with Nepali, the language of wider communication, WT has innovated relativecorrelative type of relative clauses like Eastern Tamang. It makes use of interrogative pronouns in order to make such relative clauses.

\subsection{Participial adverbial clause}

In Eastern Tamang (Lee, 2011:134; Mazaudon, 2003: 307), the participial adverbial clauses coding temporal simultaneity are formed by reduplicating the root of the verb being followed by the adverbial participial suffix-dzim/-tsim as in (15).

\begin{tabular}{|c|c|c|}
\hline $\begin{array}{l}\text { (15) ya-dze } \\
1 \text { 1sG-ERG }\end{array}$ & $\begin{array}{l}\text { bra-ba } \\
\text { walk-PAD }\end{array}$ & $\begin{array}{l}\text { tsa-tsa-dzim } \\
\text { eat-eat-PAD }\end{array}$ \\
\hline dim- & yi-dzi & \\
\hline house-LOC & go-PFV & $n$ \\
\hline
\end{tabular}

In Western Tamang, the participial adverbial clauses coding the temporal anteriority are formed by simply suffixing the participial adverbial suffix-dzim/-tsimto the root of the verb as in (16).

(16) dza-dze ken tsa-dzim bədzar ji-dzi son-ERG rice eat-PAD market go-PFV 'After having eaten rice, the son went to market.'

\subsection{Honorificity}


48 / Coding grammatical signals...

Tamang (Yonjan-Tamang, 2016:95) registers four levels honorificity: very low, mid, high and very high. ET (Lee, 2011:37) has two levels of honorificity: ordinary and honorific. WT registers two levels of honorificity: ordinary and honorific in pronouns as well as verbs as in (17a-b).

(17) a. Second person singular (middle honorific)

$\begin{array}{lll}\text { e:dze } & \text { ken } & \text { tsa-dzi } \\ \text { 2SG.MH-ERG } & \text { rice } & \text { eat-PFV } \\ \text { 'You ate rice.' } & & \end{array}$

b. Second person singular (high honorific)

$\begin{array}{lll}\text { nyan-dze } & \text { ken } & \text { sol-dzi } \\ \text { 2SG.HH-ERG } & \text { rice } & \text { eat-PFV } \\ \text { 'You ate rice.' } & & \end{array}$

5. Tamang dialects and Bodish features

Some important Bodish features include ergative case-marking, differential object marking, immediacy marking,benefactive marking, reflexive marking in all personal pronouns, causative marking,lexical nominalization, nominalized relative clauses, participial adverbial clauses and marked word order (Noonan, 2003). LaPolla (2012:126) has specified the basic features of Tamangic languages, viz., Tamang, Gurung, Manange, Nar-Phu, Thakali, Seke, Chantyal. Such features include *-pa nominalizer, *ta- prohibitive, la allative/dative/locative, ${ }^{*}$ yin copula, ${ }^{*}$ mu copula, *ta become, *-la conditional/irrealis, *ha negative, *-tsi perfective, *-si sequential converb, *-kay simultaneous converb, * (k)u imperative and $*$ e interrogative. It is to be noted here that all the major dialects of Tamang almost equally share most of the common structural features of Bodish group. However, in terms of some features such as split ergativity, immediacy marking and reflexive marking, there are dialectal variations.

Table 1: Comparison of Western Tamang with Eastern Tamang and Bodish in terms of the major features of the grammatical code

\begin{tabular}{|c|l|l|l|l|l|}
\hline SN & $\begin{array}{l}\text { Coding } \\
\text { features }\end{array}$ & WT & ET & DT* & BD** \\
\hline 1. & $\begin{array}{l}\text { Ergative case- } \\
\text { marking }\end{array}$ & $\sqrt{ }$ & $\sqrt{ }$ & $\sqrt{ }$ & $\sqrt{ }$ \\
\hline 2. & Split ergativity & $\mathrm{x}$ & $\mathrm{x}$ & $\sqrt{ }$ & $\sqrt{ }$ \\
\hline 3. & $\begin{array}{l}\text { Differential } \\
\text { object marking }\end{array}$ & $\sqrt{ }$ & $\sqrt{ }$ & $\sqrt{ }$ & $\sqrt{ }$ \\
\hline
\end{tabular}

\begin{tabular}{|c|c|c|c|c|c|}
\hline 4. & $\begin{array}{l}\text { Person/number } \\
\text { marking }\end{array}$ & $\mathrm{x}$ & $\mathrm{x}$ & $\mathrm{x}$ & $\mathrm{x}$ \\
\hline 5. & $\begin{array}{l}\text { Numeral } \\
\text { classifiers }\end{array}$ & $\sqrt{ }$ & $\sqrt{ }$ & $\sqrt{ }$ & $\mathrm{x}$ \\
\hline 6. & $\begin{array}{l}\text { Immediacy } \\
\text { marking }\end{array}$ & $\mathrm{x}$ & $\sqrt{ }$ & $\mathrm{x}$ & $\sqrt{ }$ \\
\hline 7. & $\begin{array}{l}\text { Benefactive } \\
\text { marking }\end{array}$ & $\sqrt{ }$ & $\sqrt{ }$ & $\sqrt{ }$ & $\sqrt{ }$ \\
\hline 8. & $\begin{array}{l}\text { Reflexive } \\
\text { marking in } \\
\text { all personal } \\
\text { pronouns }\end{array}$ & $\sqrt{ }$ & $\mathrm{x}$ & $\mathrm{x}$ & $\sqrt{ }$ \\
\hline 9. & $\begin{array}{l}\text { Causative } \\
\text { marking }\end{array}$ & $\sqrt{ }$ & $\sqrt{ }$ & $\sqrt{ }$ & $\mathrm{x}$ \\
\hline 10. & $\begin{array}{l}\text { Lexical } \\
\text { nominalization }\end{array}$ & $\sqrt{ }$ & $\sqrt{ }$ & $\sqrt{ }$ & $\bar{V}$ \\
\hline 11. & $\begin{array}{l}\text { Nominalized } \\
\text { relative } \\
\text { clauses } \\
\end{array}$ & $\sqrt{ }$ & $\sqrt{ }$ & $\sqrt{ }$ & $\sqrt{ }$ \\
\hline 12. & $\begin{array}{l}\text { Participial } \\
\text { adverbial } \\
\text { clauses }\end{array}$ & $\sqrt{ }$ & $\sqrt{ }$ & $\sqrt{ }$ & $\sqrt{ }$ \\
\hline 13. & $\begin{array}{l}\text { Marked } \\
\text { word-order }\end{array}$ & $\sqrt{ }$ & $\sqrt{ }$ & $\sqrt{ }$ & $\sqrt{ }$ \\
\hline 14. & $\begin{array}{l}\text { Suffixation } \\
\text { (except NEG) }\end{array}$ & $\sqrt{ }$ & $\sqrt{ }$ & $\sqrt{ }$ & $\sqrt{ }$ \\
\hline 15. & Intonation & $\sqrt{ }$ & $\sqrt{ }$ & $\sqrt{ }$ & $\sqrt{ }$ \\
\hline 16. & Stress & $\sqrt{ }$ & $\sqrt{ }$ & $\sqrt{ }$ & $\sqrt{ }$ \\
\hline
\end{tabular}

*Dhankute Tamang** Bodish group

Table 1 presents a summary of the comparison of Western Tamang with Eastern Tamang and Bodish in terms of the major features of the grammatical code.

\section{Implications of typological perspective}

It is apparent that there are some dialectal differences in the major dialects of Tamang. Comparison made from a typological perspective in Table 1 has basically two practical implications in Tamang. They are briefly discussed as follows:

\subsection{Status planning}

Article 7(2) of the federal constitution (Government of Nepal, 2015) has granted the right, by framing a state law, to determine one or more than one languages of the nation spoken by a majority of people within the state as its official language(s), in addition to the Nepali.In Province 
No. 3 Tamang as a whole stands a plurality (not majority) language with $10,12,826$ speakers.It amounts to $18 . \%$ of the total speakers of all the languages.It is the first and right candidate for being the official language.There is unintelligibility between dialects: ET and WT. Until grammatical differences are identified, the decision as to which dialects should be assigned as the official language may not take place. Thus, a comparison made from a typological perspective is highly relevant for status planning of the Tamang language.

\subsection{Corpus planning}

Unless Tamang is standardized taking dialectal differences into consideration, it will not be effectively used in administration, justice, education and mass media.Textbooks and referential materials for basic levels, grammars and dictionaries for all Tamang speech communities may not be prepared unless grammatical differences are considered.Writing in Sambota/ Tamanghik or in Devanagari scripts is still a debate among the Tamang speech communities. Except Dhankute Tamang, other Tamang dialects are tonal. In terms of grammatical features, WT is more complex than other dialects. To manage all the differences in the standardization process, typological perspective plays a highly prominent role

\section{Summary and conclusion}

In this paper, we briefly looked at coding processes of both primary and secondary grammatical signals in Western Tamang and compares, as far as possible, such process in Eastern and Dhankute dialects of Tamang. We also compared them with the common features of Bodish group of language. There are only a few differences between these dialects. Identification of dialectal differences is required for both status and corpus planning of the language. Today, rivers are not dividingbarriers for a speech community like Tamang. Kathmandu has beenserving a meeting and melting point for all dialects speakers of Tamang. The dialectal differences so far realized may be narrowed down through MLE books, grammars, dictionaries, songs and films. A more detail study has to be made to identify such dialectal differences prior to status as well as corpus planning in Tamang. Indeed, dialects are the sustenance of a language. Standardization is required for using language in office, education and communication. However, mother-tongue education should be conducted in the local dialects. In reality, the gap between the dialects is getting narrowed down in Tamang now-a-days.

$\begin{array}{ll}\text { Abbreviations } \\ 1 & \text { first person } \\ 2 & \text { second person } \\ \text { SG } & \text { singular } \\ \text { ABS } & \text { absolutive } \\ \text { CAUS } & \text { causative } \\ \text { CLF } & \text { classifier } \\ \text { DAT } & \text { dative } \\ \text { ERG } & \text { ergative } \\ \text { GEN } & \text { genitive } \\ \text { HH } & \text { high honorific } \\ \text { IMPFV } & \text { imperfective } \\ \text { LOC } & \text { locative } \\ \text { MH } & \text { middle honorific } \\ \text { NMLZ } & \text { nominalizer } \\ \text { PAD } & \text { participial adverbial } \\ \text { PFV } & \text { perfective } \\ \text { REFL } & \text { reflexive } \\ \text { RES } & \text { resultative }\end{array}$

References

Adhikari, Manju. 2015. Clause Combining in Western Tamang (As Spoken in Nuwakot). MA dissertation submitted to the Central Department of LinguisticsTribhuwan University, Nepal.

Benedict, Paul. 1972. Sino-Tibetan: A Conspectus. Cambridge: Cambridge University Press.

Bradley, David. 1997. Tibeto-Burman languages and Classification. In: Bradley, David (ed.), Papers in Southeast Asian Linguistics, No. 14: Tibeto-Burman Languages of the Himalayas, Pacific Linguistics Series A-86, 1-72. Canberra: Pacific Linguistics.

Bradley, David. 2002. The Sub-grouping of Tibeto-Burman. In: Beckwith, Christopher I (ed.), Medieval Tibeto-Burman Languages, 73-112. Leiden: Brill.

Central Bureau of Statistics /CBS. 2012. National Population and Housing Census 2011: 
50 / Coding grammatical signals...

National Report. Kathmandu: Central Bureau of Statistics.

Chalise, Krishna Prasad. 2003. The Tamang Modality System. In: Kansakar, Tej Ratna and Mark Turin (eds.), Themes in Himalayan Languages and Linguistics. 1-19. Heidelberg: South Asia Institute and Kathmandu: Tribhuvan University.

Dryer, Matthew. 1986. Primary objects, secondary objects, and antidative. Language 62.4:80845.

Eppele, John W., M. Paul Lewis, Dan Raj Regmi and Yogendra P. Yadava. eds. 2012. Ethnologue: Languages of Nepal. Kathmandu: Central Department of Linguistic sand SIL International.

Givón, T. 2001a. Syntax: An Introduction, Vol. I. Amsterdam: John Benjamins.

Givón, T. 2001b. Syntax: An Introduction, Vol.II. Amsterdam: John Benjamins.

Givón, T. 2010. The Adaptive Approach to Grammar. In: Heine, Bernd and Heiko Narrog (eds.), The Oxford Handbook of Linguistic Analysis. 27-49. Oxford: Oxford University Press.

Government of Nepal. 2015. The Constitution of Nepal. Kathmandu: Ministry of Law, Justice and Parliamentary Affairs.

Hari, Maria, Doreen Taylor and Kenneth L. Pike. 1970.Tamang Tone and Higher Levels. In Lehman, F.K (ed.), Occasional Papers of the Wolfenden Society on Tibeto-Burman Linguistics, Volume III: Tone Systems of Tibeto-Burman Languages of Nepal, Part I: Studies on Tone and Phonological Segments.82-124. Urbana: The Department of Linguistics, The University of Illinois.

LaPolla, Randy. 2012. Comments on Methodology and Evidence in Sino-Tibetan Comparative Linguistics. Language and Linguistics 13 (1): 117-132.

Lee, Sung-Woo. 2011. Eastern Tamang Grammar Sketch. MA dissertation presentedto the Faculty of the Graduate Institute of Applied Linguistics, USA.

Lipp, Timothy. 2014. A Sociolinguistic Study of Western Tamang in Nepal. Kathmandu: Linguistic Survey of Nepal (LinSuN), Central Department of Linguistics, Tribhuvan University, Nepal and SIL International.
Mazaudon, Martine. 2003. Tamang. In:Thurgood, Graham and Randy J. LaPolla (eds.), The Sino-Tibetan Languages. 291-314. London \& New York: Routledge.

Noonan, Michael. 2003. Recent Language Contact in the Nepal Himalaya. In: Bradley, David „, Randy LaPolla, Boyd Michailovsky \& Graham Thurgood (eds.), 2003. Language Variation:Papers on Variation and Change in the Sinosphere and in the Indosphere in Honour of James A. Matisoff. Canberra: Pacific Linguistics.

Owen-Smith, Thomas. 2015. Grammatical relations in Tamang, a TibetoBurmanlanguage of Nepal. PhD Thesis. SOAS, Universityof London. http://eprints.soas.ac.uk/23664.

Poudel, Kedar Prasad. 2006. Dhankute Tamang Grammar. München: LINCOM EUROPA.

Regmi, Dan Raj. 2012. A Grammar of Bhujel. München: LINCOM EUROPA.

Regmi, Ambika. 2013. A Grammar of Magar Kaike. München: LINCOM EUROPA.

Regmi, Ambika. 2017. Structural Properties of Nouns in Western Tamang. Gipan, Vol. 3.2:144-156.

Regmi, Dan Raj and Ambika Regmi. 2018. A Grammar of Western Tamang. München: LINCOM EUROPA.

Regmi, Dan Raj and Ambika Regmi. 2019. Communicative coding devices in Western Tamang: A typological perspective. In: Yonjan-Tamang, Amrit (ed.), KÄITEN (The Journal of Tamang Studies), Vol. 1.2:58-67, May-June, 2019.

SIL, 2017. Western Tamang Dictionary. https://wtamang.webonary.org/browse/?lang=e $\mathrm{n}$

Tamang, Ajitman. 1994. Basic Word Book for Tamang Language. Dading:Nepal Tamang Ghedungda.

Taylor, Doreen. 1973. Clause Patterns in Tamang. In Hale, Austin and David Watters ( eds.), Clause, Sentence, and Discourse in Selected Languages of Nepal, Part II: Clause. 81174.Norman: Summer Institute ofLinguistics, University of Oklahoma.

Thokar, Rajendra. 2015. Personal Pronouns and Morphological Constructions in Tamang. Nepalese Linguistics 30:154-160. 
Varenkamp, Bryan. 1996. Tamang Tam: A Sociolinguistic Study of Eastern Tamang Dialects (in Nepal). Kirtipur: Centre for Nepal and Asian Studies.

Yadav, Surya Prasad. 2018. A Sociolinguistic Survey of Eastern Tamang. A Report Submitted to Linguistic Survey of Nepal (LinSuN), Central Department of Linguistics, Tribhuvan University, Kathmandu.

Yonjan-Tamang. 2016. Adharbhut Tamang Vyakarana (Basic Tamang grammar). Lalitpur: NFDIN. 